\title{
The Impacts of ASEAN Labour Migration to Thailand upon the Thai Economy
}

\author{
Utis Sanglaoid $^{1}$, Sumalee Santipolvut ${ }^{1}$, Laemthai Phuwanich ${ }^{2}$ \\ ${ }^{1}$ Faculty of Economics, Department of Economics, Kasetsart University, Bangkok, Thailand \\ ${ }^{2}$ Kweang Saimai, Saimai District, Bangkok 10220, Thailand \\ Correspondence: Utis Sanglaoid, Faculty of Economics, Department of Economics, Kasetsart University 50 \\ Ngamwongwan Rd., Lardyao, Chatuchak, Bangkok 10900 Thailand. Tel: 668-4041-4409. E-mail: \\ utis24@hotmail.com
}

Received: May 26, 2014

Accepted: June 12, 2014

Online Published: July 25, 2014

doi:10.5539/ijef.v6n8p118

URL: htt://dx.doi.org/10.5539/ijef.v6n8p118

\begin{abstract}
The objective of this research is to analyse the impacts of ASEAN labour migration to Thailand upon the Thai economy. A computable general equilibrium (CGE) model is employed to investigate six economic impacts, comprising: gross domestic product (GDP), household incomes, income distributions, labour wages, exports, and imports. Two main scenarios are simulated for such impacts. The first scenario is based upon Thai foreign worker policies, which result in higher GDP, household incomes, exports, and imports but lower wages for unskilled labour and lower income distributions. The second scenario is based upon an ASEAN MRA concerning the labour movement of eight occupations: doctors, dentists, nurses, engineers, architects, accountants, surveyors, and tourism professionals. The results show impacts upon higher GDP, household incomes, income distributions, exports, and imports but lower wages for skilled labour.
\end{abstract}

Keywords: ASEAN, Thai economy, computable general equilibrium

\section{Introduction}

The Association of Southeast Asian Nations, or ASEAN, was established on 8 August 1967. The main aims and purposes of ASEAN are to accelerate economic growth, social progress, and cultural development in the region through joint endeavours in the spirit of equality and partnership, in order to strengthen the foundations for a prosperous and peaceful community of Southeast Asian Nations. In 2015, ASEAN will become the ASEAN Economic Community (AEC), creating a single market and production base under the agreement of its member countries. In particular, there exists a Mutual Recognition Agreement (MRA) about the qualifications and standards of professionals pertaining to eight mobile labour skills, comprising: doctors, dentists, nurses, engineers, architects, accountants, surveyors, and tourism professionals all under MRAs amongst ASEAN member countries. In addition to having met this setting, the immigration and work permit conditions are still in effect as independently determined by each country (ASEAN, 2013).

In 2012, the population of ASEAN countries reached 617 million, inhabiting 4.5 million square kilometres of land. Its Gross Domestic Product (GDP) was US\$2,311 billion, its trading balance was US\$602 billion and its GDP per capita was US\$3,748. Singapore has the highest GDP per capita with US $\$ 42,445$, while Myanmar has the lowest with US\$861. The GDP per capita of Thailand is US\$5,391, which is lower than those of Singapore, Brunei, and Malaysia. According to immigration data in 2011, 147,626 Thai people emigrated to other countries and 22,575 to ASEAN countries, or an equivalent of $15.92 \%$ of the total. Singapore is the destination of choice for Thai people, or the equivalent of $50.77 \%$. In 2011 the majority of migrants from ASEAN countries to Thailand were unskilled workers. Most migrant workers were from Myanmar, numbering 607,879 or $75.28 \%$ of the total from ASEAN regions in Thailand. Migrant workers from Cambodia were ranked second accounting for 118,516 or $14.64 \%$, those from Laos were third highest with 71,336 or $8.81 \%$. During the studied period, Thailand established a policy enabling unskilled labour mobility from neighbouring countries to enter the country. That policy permitted migrant workers, especially Burmese, Lao, and Cambodians, with or without existing work permits, to register for work in Thailand in 2004 and 2009. This policy increased the number of migrant workers from 296,184 in 2003 to 858,719 in 2004; an increase of $189.93 \%$. In 2008 , the number of migrant workers was 529,629 and reached 
$1,435,398$ in 2009 , equivalent to an increase of $171.02 \%$. If Thailand implements this policy which may increase numbers of migrant workers again, what the impact will be on the Thai economic system is still questionable.

Due to the commencement of the AEC in 2015, there are concerns about the free flow of labour, as defined in the agreements. Based upon a theoretical hypothesis, the free flow of labour will enable more flexibility in labour markets. Skilled workers will have more career choices suited to their potential, thereby maximising their incomes. As a result, the target countries for skilled workers will gain benefits from these highly skilled workers. On the other hand, some industries may be affected by the flow of skilled labour due to competition in the local workforce. Furthermore, the flow of skilled labour between the associated countries can lead to a loss of skilled labour in the countries from which they originated. That is, the free flow of skilled labour will have an effect on the highly competitive labour market creating both advantages and disadvantages.

As mentioned above, empirical studies on the impacts of flows of skilled and unskilled ASEAN labour migration to Thailand upon the Thai economy have not been investigated in depth. Therefore, the impacts of ASEAN labour migration upon the Thai economic system is of great interest and would make a significant contribution to this field of study.

The remainder of this paper is organised as follows: a literature review in section 2 introduces a brief background, and shows the CGE model specifications employed in this study. Section 3 describes the methodology. Section 4 addresses the results and discussion, and the conclusion is set out in section 5 .

\section{Literature Reviews}

Theories and thoughts involving evaluation of the impacts of international migration upon economic systems could be explained by the following hypotheses. Borjas (1987) stated that immigration might increase the GDP of a destination country because international migration occurs from the expectations of migrants for higher economic welfare. The movement of foreign workers might make the labour market in a destination country more competitive, and the replacement of existing workers may lead to declines in income and unemployment in specific careers, or greater unemployment in general. In addition, immigration might cause a surplus in the balance of payments for the destination country.

A computable general equilibrium model (CGE) is the main analytical tool used to deal with the impacts upon economic systems, income distributions, wages, and international trade.

Sarris and Zografakis (1999) explored the impacts of illegal migration upon economic systems. They quantitatively assessed the impact of illegal migration upon the Greek economy in the short term, by employing a CGE model. They found that an increase in GDP resulted from the immigration of unskilled workers. Similarly, Hubertus and Thomas (2001) studied the impact of expanding member nations on the European Union. They also investigated the impact on the participation of Central and Eastern European countries in the EU and the impact of labour mobility upon the economies of related countries. A CGE created by Purdue University was adapted. They created two simulations, including one that applied economic liberalisation to every aspect and another that applied labour mobility. The findings revealed that economic liberalisation increased the GDP of destination countries, while it decreased the GDP of those countries of migrant origin. In the area of labour mobility, the GDP of countries of origin decreased, while the GDP of destination countries increased. Moreover, Baas and Brucker (2008) studied the impact of international labour mobility upon economies. They mentioned that, in 2004, the European Union accepted nations from Central and Eastern Europe, so it was anticipated that there would be workers from Central and Eastern Europe who gained higher per capita incomes than those of Britain and Germany. Based upon this anticipation, they created a simulation to analyse the impacts upon those economies and found that both Britain and Germany were similar. Private sector and government consumption, tax incomes of governments, factors involving per capita incomes and employment all increased.

In studies involving income distribution, Sarris and Zografakis (1999) also pointed out that illegal immigration decreased the real incomes in household sectors of unskilled workers, in both low and middle income levels. In other groups, the household sectors had higher real incomes. It was revealed that more than $37 \%$ of the population of Greece lost many benefits through illegal immigration.

For impacts upon labour markets, Baas and Brucker (2008) utilized two simulations. The first one demonstrated that Germany did not accept the free flow of labour, while Britain permitted it, and yet there were higher employment rates found in both countries. However, wages in Britain were higher than the wages in Germany, and the unemployment rate in Britain was lower than that of Germany. The second simulation represented the free flow of labour within EU member nations, whereby the impacts upon Germany and Britain were consistent in that the employment rates of both countries had risen. Nevertheless, the difference was that wages in Britain were higher 
than those in Germany, and the unemployment rate in Britain was lower than that of Germany. Therefore, the results of both simulations were consistent. Similarly, a study by Reed and Latorre (2009) who explored the impact of immigration upon the United Kingdom, showed that workers would gain lower wages when there was greater immigration of migrant workers.

Sarris and Zografakis (1999), Hubertus and Thomas (2001), and Baas and Brucker (2008) all investigated the impacts of higher numbers of migrant workers upon international trading. Therefore, when there are higher numbers of migrant workers, international trading in destination countries will increase and this can be seen through higher net exports.

In this study, a CGE is employed to emphasise the analysis of the impact of ASEAN labour migration upon the Thai economy. The investigation involves the Thai economy as a whole, which can be measured using GDP, household income, income distribution measured using the GINI coefficient, wages, imports, and exports.

\section{Methodology}

As previously mentioned, this study applies a computable general equilibrium model (CGE) based upon Warlas' Law. This states that if there are changes in an economy due to exogenous variables, such as a change in the number of workers, resulting in an imbalance within the economic system, then there will be an adjustment to the equilibrium. In this study, two scenarios are created representing changes in the number of workers. The first scenario is based upon implementation of the policy allowing existing registered and non-registered migrant workers from Myanmar, Laos, and Cambodia to register for work in Thailand. The second scenario is based upon the free flow of skilled labour in eight professions under ASEAN MRAs, which include: doctors, dentists, nurses, engineers, architects, accountants, surveyors, and tourism professionals.

The CGE model was developed from an input-output model and a social accounting matrix model. The difference between the input-output model and social accounting matrix model is that the second model includes the consideration of household sectors. Both models could analyse the outcome of variables in terms of values only. They could not reveal changes of value if they came in the form of price or quantity. Conversely, the CGE model could differentiate the relationship of variables in terms of price and quantity. The information in the input-output table used in this study is from the 'Office of the National Economic and Social Development Board of Thailand'.

The general equilibrium model states that if an economic system has an $n$ market and if $n-1$ is in equilibrium, although there are external factors affecting the market equilibrium, then there will be an adjustment to the rest in order to reach equilibrium again. As a result, all markets are in equilibrium accordingly.

To apply the CGE model to analyse the impact of labour flow, Phuwanich's model was used (Phuwanich, 2008). This model is based upon the behaviour of producers, consumers, and the government and demonstrates the relationships between them. The model shows how changes in the number of workers flowing from ASEAN countries affect the Thai economy. The model consists of three steps, including: conceptual framework development, data collection, and the development of a general equilibrium model and its analysis, respectively. The conceptual framework defines the elements of an economic system and identifies the type of production activity, institution, and behaviour of economic units. Subsequently, data from each element is illustrated through social accounting matrices (SAM). The final stage compiles all the information and links it together, using SAM as the centre.

Figure 1 represents the conceptual framework development and starts with types of production activities derived from national income accounts, including eleven activities, four institutions, and ten households divided into ten levels, from juristic persons, government, and the foreign sector. Identification levels and type of supply functions are completed as follows: Level 1 is a Leontief (LEO) production function comprising two types, which are the basic and intermediate factors of production functions. Level 2 comprises two parts: the first part being the basic factor which is a Constant Elasticity Substitution (CES) function. This part contains three factors: unskilled labour, skilled labour, and capital. The second part is the intermediate factor of production, which is also a Leontief (LEO) function. This part includes eleven factors of production activities.

Demand functions identify a utility as a Linear Expenditure System (LES), including eleven production activities. Identification of the levels and types of international trading functions, in terms of export, is based upon Constant Elasticity Substitution of Transformation (CET). It covers national consumption and exports. Imports are based upon the Constant Elasticity Substitution (CES) invented by Armington. It covers national production and imports. The aforementioned conceptual framework is set and then some major variables in structural equations are created and used to analyse the impact of labour flow upon the Thai economy, as illustrated in 
Figure 2. The model of this study divides variables into two groups; endogenous variable and exogenous variable. Exogenous variables determine a change of model including the numbers of migrants. Excel software with the Newton-Raphson method is the utilized program for the analysis of such impacts.

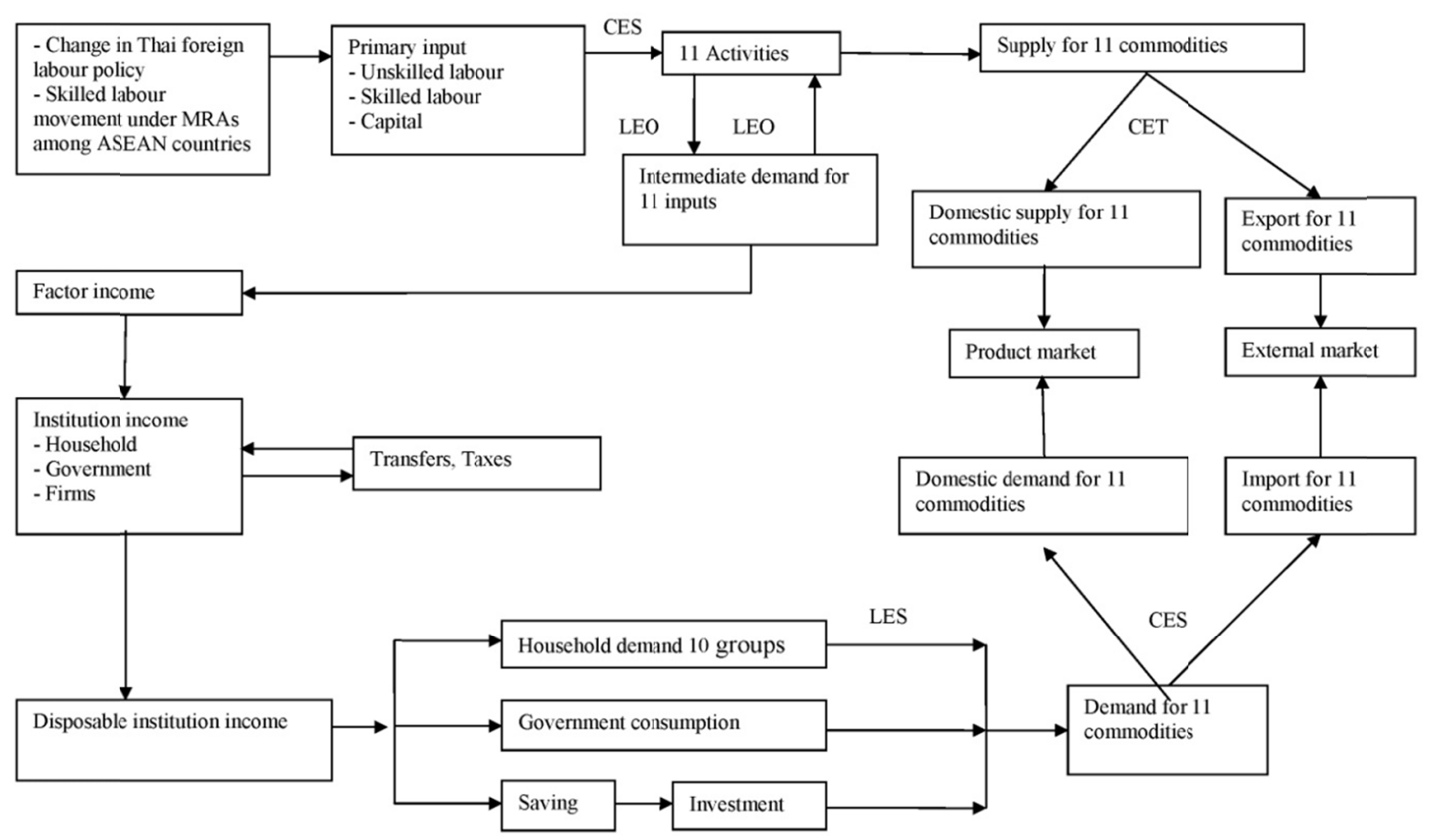

Figure 1. CGE flow chart

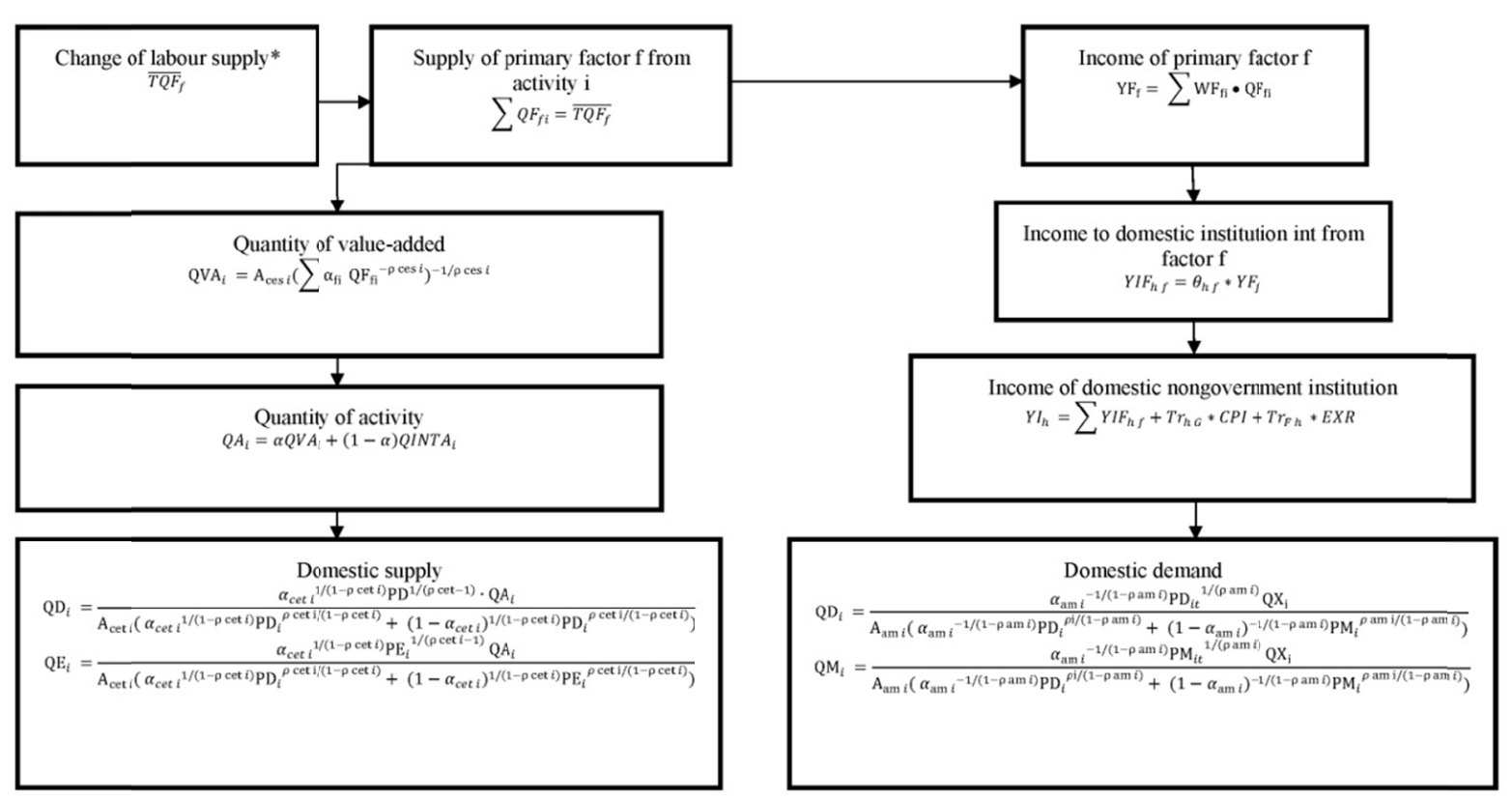

Figure 2. Diagram of relationship of main variables in structural equations

Note. * changes in number of labourers from Thai foreign labour policy and ASEAN MRAs. 


\section{Results and Discussion}

Analyses of the impacts of ASEAN labour migration to Thailand upon the Thai economy by the CGE model provide two main scenarios. The details are discussed as follows:

\section{Scenario 1: Impacts of Changes to Thai Foreign Worker Policies}

The impacts of foreign worker policies in Thailand upon the Thai economy are divided into two cases. The first case analyses the impact of ASEAN labour migration to Thailand upon the Thai economic system, based upon changes in the number of workers according to the coefficient of migrant worker policies from a study entitled 'Determinants of Intra-ASEAN labour migration to Thailand' (Sanglaoid, Santipolvut \& Thamma-Apiroam, 2014). The coefficient is 68.17 (Note 1) and is used to calculate the increasing rate of workers in Thailand, which is equivalent to $3.30 \%$.

The second case is based upon a database from the 'Ministry of Labour', Department of Employment, and the 'Office of Migrant Workers Administration'. In 2004 and 2009, there was a foreign worker policy affecting a number of migrant workers. This policy allowed migrant workers, especially those from Burma, Laos, and Cambodia with or without work permits, to register for work in Thailand. These migrant workers could remedy the lack of labour in Thailand. Furthermore, this policy could solve illegal immigrant labour problems. As a result, the numbers of migrant workers obviously increased. In 2004, the number of migrant workers was $189.99 \%$, and measured $171.02 \%$ in 2009 . Thus the average change in the number of migrant workers under this policy during the two periods reached $180.51 \%$, and this was used to calculate the increasing rate of labour in Thailand, which was equivalent to $7.78 \%$.

An analysis of the results of the two cases is shown in Table 1. These two cases indicate similar results excluding the size of the impacts. Therefore, when the numbers of migrant workers, mainly unskilled, increased due to migrant worker policy establishment, the impacts are in line with a theory stating that when the number of workers in a country increases, this results in higher available resources for production. Thai economic systems were affected, although the increase in GDP included the value of eleven production activities. The construction sector was highly affected by a change in the amount of labour. In case 1, the change in GDP included the value of eleven production activities and was measured at $0.1123 \%$ compared with $0.1914 \%$ in case 2 .

An increase in the number of unskilled workers in Thailand also resulted in higher income achievement at each level. On average, the change in household incomes was $0.2349 \%$ in case 1 , which is lower than $0.4397 \%$ for case 2.

An increase in the number of migrant workers also resulted in a higher amount of unskilled labour in Thailand. Wages for unskilled workers decreased by $4.0169 \%$ in case 1 and $8.0122 \%$ in case 2 , but wages for skilled labour increased by $0.0167 \%$ in case 1 and $0.0358 \%$ in case 2, respectively. Thus, income inequality increased due to the higher wages of skilled workers but lower wages for unskilled workers, which was reflected by an increase in percentage change to the Gini coefficient of 0.5346 in case 1 and 1.2476 in case 2, respectively.

Exports in 11 production activities tended to increase, except in the electricity and water supply sectors. These increases were $0.0265 \%$ in case 1 and $0.0905 \%$ in case 2, respectively. Exports in the construction sector tended to see drastic changes, as well as an increase in imports for 11 production activities. These increases were $0.1449 \%$ in case 1 and $0.1861 \%$ in case 2 , respectively.

The findings from both cases were similar, but different in the areas of impact size, indicating that impacts in case 1 were smaller than those of case 2, because for case 1 the numbers of unskilled workers increased less than in case 2 .

\section{Scenario 2: Impacts of Skilled Labour Flow based upon ASEAN MRAs}

Since there is no data available regarding changes to the labour figures in the eight professions in Thailand, net migration rates were applied to the European Union (EU) in 2004, a period which accepted new member nations, whereby some member nations such as Germany allowed labour mobility within other EU member nations. As a result, data from the CIA World Fact Book 2010 indicates that the net migration rate of Germany changed from $2.35 \%$ in 2003 to $2.91 \%$ in 2004 . Thus, the change in net migration was $23.28 \%$, and this was used to calculate the increasing rate of skilled workers in Thailand, resulting in the eight professions of mobility based upon ASEAN MRAs being equivalent to $0.39 \%$.

It is assumed that the eight professions mainly moved within the service sectors. Table 1 reveals that the increase in the number of skilled workers resulted in an increase in GDP at $0.0021 \%$. However, this impact is lower than that of scenario 1 . The construction sector was the most positively affected amongst all 11 production activities. 
The higher numbers of skilled workers in Thailand, especially those in the service sector, resulted in the achievement of higher incomes at each level. On average, the increase in household income was $0.0042 \%$.

For the higher number of skilled workers, lower skilled worker wages rose by $0.0047 \%$, but unskilled worker wages increased by only $0.0001 \%$. As a consequence, income inequality decreased and was reflected by a $0.0012 \%$ decrease in the Gini coefficient.

Exports in all 11 production activities tended to decrease by $0.0009 \%$, whereas imports tended to increase by $0.0031 \%$. Imports in the construction sector tended to see drastic changes, much more so than others.

Comparatively, the impacts of skilled labour migration, specifically in the eight professional occupations are simulated, rather than the minimal impacts on the Thai economy, as shown in case 3 . This is because the numbers in such labour migration were still lower than those of unskilled workers. There are several obstacles for skilled labour movement amongst ASEAN countries, such as occupational qualifications and standards, language barriers and, last but not least, the work permit regulations of each member country, which have not yet been adjusted in line with the ASEAN MRA labour movement policy.

Table 1. The impact of ASEAN labour migration to Thailand upon the Thai economy

\begin{tabular}{|c|c|c|c|}
\hline \multirow{2}{*}{ Variable } & \multicolumn{2}{|c|}{$\begin{array}{c}\text { Scenario 1: Impacts of Change in Thai Foreign } \\
\text { Worker Policies }\end{array}$} & \multirow{2}{*}{$\begin{array}{l}\text { Scenario 2: Impacts of skilled labour } \\
\text { flow based upon ASEAN MRAs } \\
\text { Case } 3 * * * \\
\text { (Percentage Change) }\end{array}$} \\
\hline & $\begin{array}{c}\text { Case } 1 * \\
\text { (Percentage Change) }\end{array}$ & $\begin{array}{c}\text { Case } 2 * * \\
\text { (Percentage Change) }\end{array}$ & \\
\hline Gross Domestic Product & 0.1123 & 0.1914 & 0.0021 \\
\hline Household Incomes & 0.2349 & 0.4397 & 0.0042 \\
\hline Wages of unskilled workers & -4.0169 & -8.0112 & 0.0001 \\
\hline Wages of skilled workers & 0.0167 & 0.0358 & -0.0047 \\
\hline Income Distributions (Gini Coefficient) & 0.5346 & 1.2476 & -0.0012 \\
\hline Value of 11 production activities & 0.1123 & 0.1914 & 0.0021 \\
\hline 1. Agriculture & 0.1246 & 0.2817 & 0.0007 \\
\hline 2. Mining and Quarrying & 0.1312 & 0.3121 & -0.0006 \\
\hline 3. Manufacturing & 0.0537 & 0.1706 & -0.0006 \\
\hline 4. Construction & 0.7043 & 0.5812 & 0.0171 \\
\hline 5. Electricity, Gas and Water Supply & 0.2676 & 0.5497 & 0.0027 \\
\hline 6. Transport & 0.1939 & 0.3481 & 0.0025 \\
\hline 7. Wholesale and Retail Trade & 0.1764 & 0.2914 & 0.0021 \\
\hline 8. Financial Intermediation & 0.1730 & 0.3475 & 0.0017 \\
\hline 9. Real Estate & 0.1725 & 0.3371 & 0.0018 \\
\hline $\begin{array}{l}\text { 10. Public Administration and Defense: } \\
\text { Compulsory Social Security }\end{array}$ & 0.0777 & 0.1724 & 0.0000 \\
\hline 11. Service & 0.1788 & 0.3683 & 0.0016 \\
\hline Export value of 11 production activities & 0.0265 & 0.0905 & -0.0009 \\
\hline 1. Agriculture & 0.0457 & 0.1402 & -0.0016 \\
\hline 2. Mining and Quarrying & 0.0651 & 0.1931 & -0.0020 \\
\hline 3. Manufacturing & 0.0487 & 0.1623 & -0.0007 \\
\hline 4. Construction & 0.1211 & 0.4124 & -0.0029 \\
\hline 5. Electricity, Gas and Water Supply & -0.0158 & -0.0042 & -0.0014 \\
\hline 6. Transport & 0.0000 & 0.0000 & 0.0000 \\
\hline 7. Wholesale and Retail Trade & 0.0268 & 0.0912 & -0.0010 \\
\hline 8. Financial Intermediation & 0.0000 & 0.0000 & 0.0000 \\
\hline 9. Real Estate & 0.0000 & 0.0000 & 0.0000 \\
\hline $\begin{array}{l}\text { 10. Public Administration and Defense: } \\
\text { Compulsory Social Security }\end{array}$ & 0.0000 & 0.0000 & 0.0000 \\
\hline 11. Service & 0.0000 & 0.0000 & 0.0000 \\
\hline Import value of 11 production activities & 0.1449 & 0.1861 & 0.0031 \\
\hline 1. Agriculture & 0.1140 & 0.2437 & 0.0014 \\
\hline 2. Mining and Quarrying & 0.0963 & 0.1920 & 0.0011 \\
\hline 3. Manufacturing & 0.2963 & 0.5074 & 0.0051 \\
\hline
\end{tabular}




\begin{tabular}{|c|c|c|c|}
\hline 4. Construction & 0.6151 & 0.2718 & 0.0194 \\
\hline 5. Electricity, Gas and Water Supply & 0.2921 & 0.5776 & 0.0040 \\
\hline 6. Transport & 0.0000 & 0.0000 & 0.0000 \\
\hline 7. Wholesale and Retail Trade & 0.1802 & 0.2549 & 0.0034 \\
\hline 8. Financial Intermediation & 0.0000 & 0.0000 & 0.0000 \\
\hline 9. Real Estate & 0.0000 & 0.0000 & 0.0000 \\
\hline $\begin{array}{l}\text { 10. Public Administration and Defense: } \\
\text { Compulsory Social Security }\end{array}$ & 0.0000 & 0.0000 & 0.0000 \\
\hline 11. Service & 0.0000 & 0.0000 & 0.0000 \\
\hline
\end{tabular}

\section{Conclusion}

This study aimed to analyse the impacts of ASEAN labour migration to Thailand upon the Thai economy by employing CGE analysis. The findings reveal two cases of scenario I, based upon the establishment of a policy concerning hiring newly-registered migrant workers and registered unskilled migrant workers from Myanmar, Laos, and Cambodia; in that it increased the GDP of household income, imports, and exports but decreased unskilled worker wages and reduced the equality of income distributions. All of these impact sizes depended upon the numbers of unskilled migrants. For scenario II, the free flow of eight professions, based upon ASEAN MRAs, were expected to increase the numbers of skilled workers. Such an increase in skilled workers resulted in an increase in GDP, household income, exports, and more equal income distributions but decreased skilled worker wages and imports. In summary, policies which increase the numbers of both unskilled and skilled workers in Thailand are likely to benefit the Thai economy. Therefore, it is essential to emphasise more coherent policies: specifically the impacts of skilled labour movement in eight professions are rather limited in the short-term. This is because the ASEAN member states continue to have their own work permit regulations. Nevertheless, the simulated economic benefits from professional movements in this study should lead to dramatic concerns about ASEAN skilled labour movements. More collaboration in common labour standards and development might cause the free flow of skilled labour between ASEAN member states to become more effective and, eventually, fulfill the main aims and purposes of the AEC.

\section{References}

Baas, T., \& Brucker, H. (2008). Macroeconomic Impact of Eastern Enlargement on Germany and UK: Evidence from a CGE Model. Applied Economics Letters, 17(2), 125-128. http://dx.doi.org/10.1080/13504850701720098

Bacharach, M. (1970). Biproportional Matrices and Input-Output Change. Cambridge: Cambridge University Press. http://dx.doi.org/10.1080/0953531042000219259

Bodvarsson, O. B., \& Berg, H. V. (2009). The economics of immigration: Theory and policy. Springer, New York. http://dx.doi.org/10.1007/978-1-4614-2116-0_1

Borjas, G. J. (1987). Self-selection and the earning of immigrant. The American Economic Review, 77(4), 531553.

Hille, H., \& Straubhaar, T. (2001). The Impact of EU-Enlargement on Migration Movements and Economic Integration: Results of Recent Studies. Paris: Organisation for Economic Co-operation and Development Press.

International Monetary Fund. (2010). World Economic Outlook Report. Retrieved from http://www.imf.org/external/pubs/ft/weo/2011/01/weodata/index.aspx

Ministry of Labour, Department of Employment, Office of Foreign Workers Administration. (2011). Remaining numbers of foreigners with work permission in Thailand as of December 2006-2011. Retrieved from http://www.overseas.doe.go.th/statistic.php

Ministry of Labour, Department of Employment, Thailand Overseas Employment Admission. (2011). Numbers of Thai labourers emigrated within ASEAN countries in 2005-2011. Retrieved from http://www.overseas.doe.go.th/statistic.php

Phuwanich, L. (2008). Policies for Efficient Water Resource Management in Thailand. Thailand: Ph.D. Thesis, Kasetsart University. 
Reed, H., \& Lotorre, M. (2009). The economic impacts of migration on the UK labour market. Retrieved from http://www.newunionism.net/ContentPages/50595219.pdf

Sadoulet, E., \& Janvry, A. D. (1995). Quantitative Development Policy Analysis. London: The John Hopkin University Press.

Sanglaoid, U., Santipolrut, S., \& Thamma-Apiroam, R. (2014). Determinant of Intra-ASEAN Labour Migration to Thailand. Asian Social Science, 10(7), 1-6. http://dx.doi.org/10.5539/ass.v10n8p66

Sarris, A., \& Zografakis, S. (1999). A computable general equilibrium assessment of the impact of illegal immigration on the Greek economy. Journal of Populantion Economics, 12, 155-182. http://dx.doi.org/10.1007/s001480050095

The Association of Southeast Asian Nations. (2013). ASEAN Overview. Retrieved from $\mathrm{http}: / / \mathrm{www}$.asean.org/asean/about-asean/overview

The World Bank. (2011). GDP per capita based on purchasing power parity (PPP). Retrieved from $\mathrm{http}: / /$ data.worldbank.org/indicator/NY.GDP.PCAP.PP.CD

Timothy, J. H. (1995). A Model of U.K. Emigration, 1870-1913. The Review of Economics and Statistics, 77(3), 407-415. http://dx.doi.org/10.2307/2109903

\section{Note}

Note 1. $\mathrm{M}_{\mathrm{h} \text { thai }}=-108.87+227.12 \ln \left(\frac{\mathrm{pgdp}_{\text {thai }}}{\mathrm{pgdp}_{\mathrm{h}}}\right)_{\mathrm{t}}+46.97 \ln \left(\frac{\mathrm{e}_{\text {thai }}}{\mathrm{e}_{\mathrm{h}}}\right)_{\mathrm{t}}+0.21 \mathrm{MST}_{\mathrm{h} \text { thai }}+0.04 \mathrm{M}_{\mathrm{h} \text { thai }-1}+68.77 \mathrm{P}_{\mathrm{h} \text { thai }}+\varepsilon_{\mathrm{h} \text { thai }}$

$M_{h \text { thait }}$ is the net migration rate from countries in ASEAN (h) to Thailand at time (t); $p g d p_{\text {thait }}$ is per capita GDP (PPP) in Thailand at time (t); $p g d p_{h t}$ is per capita GDP (PPP) in countries in ASEAN (h) at time (t); $e_{\text {thai }}$ is employment rate of Thailand at time $\mathrm{t}, e_{h t}$ is the employment rate of countries in ASEAN (h) at time $(\mathrm{t}) ; M S T_{h f t}$ is migration stock at time $\mathrm{t}$ and $P_{h \text { thait }}$ is the migration worker policy of Thailand at time (t).

\section{Appendix A. Abridged Mathematical CGE Model}

\begin{tabular}{|c|c|}
\hline & Equations \\
\hline$(1)$ & $\mathrm{QINTA}_{i}=\mathrm{INTA}_{i} * \mathrm{QA}_{i}$ \\
\hline (2) & $\mathrm{QVA}_{i}=\mathrm{IVA}_{i} * \mathrm{QA}_{i}$ \\
\hline (3) & $\mathrm{QVA}_{i}=\mathrm{A}_{\operatorname{ces} i}\left(\sum \alpha_{\mathrm{fi}} \mathrm{QF}_{\mathrm{fi}}^{-\rho \operatorname{ces} i}\right)^{-1 / \rho \operatorname{ces} i}$ \\
\hline (4) & $\mathrm{WF}_{\mathrm{i}} *$ WFDIST $_{\mathrm{fi}}=\mathrm{PVA}_{\mathrm{i}} * \mathrm{QVA}_{\mathrm{i}}\left(\sum \alpha_{\mathrm{fi}} * \mathrm{QF}_{\mathrm{fi}}^{-\rho \operatorname{ces} \mathrm{i}}\right)^{-1} * \alpha_{\mathrm{fi}} * \mathrm{QF}_{\mathrm{fi}}^{-\rho \operatorname{ces} i-1}$ \\
\hline (5) & $\mathrm{QINT}_{i j}=\mathrm{A}_{\mathrm{ij}} * \mathrm{QINTA}_{i}$ \\
\hline (6) & $\mathrm{QA}_{i}=\mathrm{A}_{\text {cet } i}\left(\alpha_{\text {cet } i} \mathrm{QD}_{i}^{-\rho \operatorname{cet} i}+\left(1-\alpha_{\text {cet } i}\right) \mathrm{QE}_{i}^{-\rho \operatorname{cet} i}\right)^{1 / \rho \operatorname{cet} i}$ \\
\hline (7) & 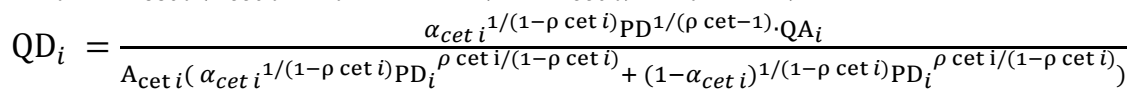 \\
\hline (8) & 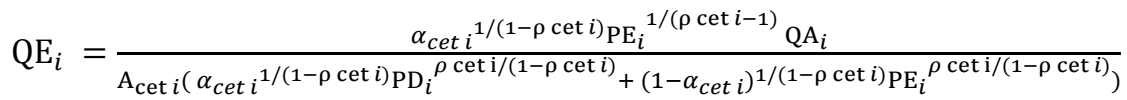 \\
\hline (9) & $\mathrm{QX}_{i}=\mathrm{A}_{\mathrm{am} i}\left(\alpha_{\mathrm{am} i} \mathrm{QAD}_{i}^{-\rho \mathrm{am} i}+\left(1-\alpha_{\mathrm{am} i}\right) \mathrm{QM}_{i}^{-\rho \mathrm{am} i}\right)^{-1 / \rho \mathrm{am} i}$ \\
\hline (10) & $\mathrm{QD}_{i}=\frac{\alpha_{\mathrm{am} i} i^{-1 /(1-\rho \mathrm{am} i)} \mathrm{PD}_{i t}{ }^{1 /(\rho \mathrm{am} i)} \mathrm{QX}_{\mathrm{I}}}{\mathrm{A}_{\mathrm{am} i} i\left(\alpha_{\mathrm{am} i} i^{-1 /(1-\rho \mathrm{am} i)} \mathrm{PD}_{i}{ }^{i /(1-\rho \mathrm{am} i)}+\left(1-\alpha_{\mathrm{am} i}\right)^{-1 /(1-\rho \mathrm{am} i)} \mathrm{PM}_{i}{ }^{\rho \mathrm{am} \mathrm{i} /(1-\rho \mathrm{am} i)}\right)}$ \\
\hline (11) & $\mathrm{QM}_{i}=\frac{\alpha_{\mathrm{am} i} i^{-1 /(1-\rho \mathrm{am} i)} \mathrm{PM}_{i t}{ }^{1 /(\rho \mathrm{am} i)} \mathrm{QX}_{\mathrm{I}}}{\mathrm{A}_{\mathrm{am} i}\left(\alpha_{\mathrm{am}} i^{-1 /(1-\rho \mathrm{am} i)} \mathrm{PD}_{i}{ }^{\rho /(1-\rho \mathrm{am} i)}+\left(1-\alpha_{\mathrm{am} i}\right)^{-1 /(1-\rho \mathrm{am} i)} \mathrm{PM}_{i}{ }^{\rho \mathrm{am} \mathrm{i} /(1-\rho \mathrm{am} i)}\right)}$ \\
\hline (12) & $\mathrm{YF}_{\mathrm{f}}=\sum \mathrm{WF}_{\mathrm{fi}} \bullet \mathrm{QF}_{\mathrm{fi}}$ \\
\hline (13) & $Y I F_{h f}=\theta_{h f} * Y F_{f}$ \\
\hline (14) & $\mathrm{BI}_{\mathrm{bf}}=\theta_{\mathrm{bf}} * \mathrm{YF}_{\mathrm{f}}$ \\
\hline$(15)$ & $Y I_{h}=\sum Y I F_{h f}+\operatorname{Tr}_{G h} * C P I+\operatorname{Tr}_{F h} * E X R$ \\
\hline (16) & $\mathrm{BI}=\sum \mathrm{BI}_{\mathrm{bf}}+\operatorname{Tr}_{\mathrm{Fb}} * \mathrm{EXR}$ \\
\hline (17) & $\mathrm{GI}=\bar{\sum} \operatorname{Tin} * \mathrm{YI}+\sum \mathrm{QA}_{\mathrm{i}} * \mathrm{Ta}_{\mathrm{i}}+\sum \mathrm{QVA}_{\mathrm{i}} * \mathrm{Rva}_{\mathrm{i}}+\sum \mathrm{QM}_{\mathrm{i}} * \mathrm{Tm}_{\mathrm{i}}+\sum \mathrm{QE}_{\mathrm{t}} * \mathrm{Te}_{\mathrm{i}}$ \\
\hline (18) & $\mathrm{U}_{\mathrm{h}}=\sum \beta \mathrm{i} \operatorname{In}\left(\mathrm{CHQC}_{\mathrm{hi}}-\mathrm{CHQC}_{\mathrm{li}}\right)$ \\
\hline
\end{tabular}


(19) $\mathrm{CHQC}_{\mathrm{hi}}=\mathrm{CHQCL}_{\mathrm{hi}}+\frac{\beta}{\mathrm{PC}_{\mathrm{i}}} *\left(\mathrm{BH}_{\mathrm{h}}-\sum \mathrm{PC}_{\mathrm{i}} * \mathrm{CHQCL}_{\mathrm{hi}}\right)$

(20) $\mathrm{QINV}_{\mathrm{i}}=\theta \operatorname{inv}_{\mathrm{i}} * \overline{\mathrm{QINV}_{1}}$

(21) $\mathrm{EG}=\sum \mathrm{PC}_{\mathrm{i}} * \mathrm{QC}_{\mathrm{i}}+\mathrm{Tr}_{\mathrm{Gh}} * \mathrm{CPI}$

(22) $O G_{i}=\overline{O G}_{i}$

(23) $\quad \mathrm{PM}_{\mathrm{i}}=\operatorname{pwm}_{\mathrm{i}}\left(1-\mathrm{T}_{\mathrm{mi}}\right) * E X R$

(24) $\quad \mathrm{PE}_{\mathrm{i}}=\operatorname{pwe}_{\mathrm{i}}\left(1-\mathrm{T}_{\mathrm{ei}}\right) * E X R$

(25) $\mathrm{PC}_{\mathrm{i}}=\left(\mathrm{PD}_{\mathrm{i}} * \mathrm{QD}_{\mathrm{i}}+\mathrm{PE}_{\mathrm{i}} * \mathrm{QE}_{\mathrm{i}}\right) /\left(\mathrm{QD}_{\mathrm{i}}-\mathrm{QE}_{\mathrm{i}}\right)$

(26) $\quad \mathrm{PD}_{\mathrm{i}}=\mathrm{PA}_{\mathrm{i}}\left(1-\mathrm{T}_{\mathrm{ai}}\right)$

(27) $\mathrm{PVA}_{\mathrm{i}}=\mathrm{PA}_{\mathrm{i}}-\mathrm{PQINT}_{\mathrm{i}}$

(28) $P Q I N T_{i}=\sum P C_{i} * A_{i j}$

(29) $\quad \mathrm{CPI}=\Sigma \mathrm{PC}_{\mathrm{i}} * \mathrm{cwts}_{\mathrm{i}}$

(30) $\sum Q F_{f i}=\overline{T Q F_{f}}$

(31) $\mathrm{QC}_{\mathrm{i}}=\mathrm{PQINT}_{\mathrm{i}}+\sum \mathrm{CHQCA}_{\mathrm{hi}}+\mathrm{GCQC}_{\mathrm{i}}+\mathrm{BINV}_{\mathrm{i}}+\mathrm{GINV}_{\mathrm{i}}$

(32) $\quad \sum \mathrm{PM} \bullet \mathrm{QM}_{\mathrm{i}}=\sum \mathrm{PE} \bullet \mathrm{QE}_{\mathrm{i}}+\mathrm{FS}$

(33) $\quad \mathrm{GI}=\mathrm{EG}+\mathrm{GS}$

(34) $\sum$ MPS $\bullet\left(\mathrm{YI}_{\mathrm{h}} \bullet\left(1+\mathrm{Tins}_{\mathrm{h}}\right)\right)+\mathrm{GS}+\mathrm{BS}+\mathrm{FS} \bullet \mathrm{EXR}=\sum \mathrm{QINV}_{\mathrm{i}} \bullet \mathrm{PC}_{\mathrm{i}}$

Definitions of Model Parameters/variables.

Sets

$i \in I$ : commodities;

$i \in I M$ : imported commodities;

$i \in I E$ : exported commodities;

$j \in J$ : intermediate inputs;

$f \in F$ : primary inputs;

$f \in F$ : households.

\section{Endogenous Variables}

$\mathrm{QA}_{\mathrm{i}}$ : quantity (level) of activity;

$\mathrm{QVA}_{\mathrm{i}}$ : quantity of (aggregate) value-added;

QINTA $_{\mathrm{i}}$ : quantity of aggregate intermediate input;

QINT $_{i j}$ : quantity of intermediate input $j$ to activity $i$;

$\mathrm{QF}_{\mathrm{fi}}$ : quantity demand of primary input $\mathrm{f}$ from activity $\mathrm{i}$;

$\mathrm{QD}_{\mathrm{i}}$ : quantity sold domestically of domestic output;

$\mathrm{QE}_{\mathrm{i}}$ : quantity export commodity;

$\mathrm{QM}_{\mathrm{it}}$ : quantity import commodity;

$\mathrm{CHQC}_{\mathrm{hi}}$ : minimum quantity consumed of commodity $\mathrm{i}$ by household $\mathrm{h}$;

$\mathrm{CHQC}_{\mathrm{hi}}$ : quantity consumed of commodity $\mathrm{i}$ by household $\mathrm{h}$;

$\mathrm{BH}_{\mathrm{h}}$ : personal income minus personal taxes and savings;

QINV $_{\mathrm{i}}$ : quantity of investment demand for commodity;

$\mathrm{QG}_{\mathrm{i}}$ : government consumption demand for commodity;

GI: government income.

\section{Exogeneous Variable}

$\mathrm{TQF}_{\mathrm{f}}$ : quantity supply of primary input $\mathrm{f}$;

$\mathrm{PVA}_{\mathrm{i}}$ : value-added price; 
$\mathrm{PC}_{\mathrm{i}}$ : average price for sold domestically;

PDi: price for commodity produced and sold domestically;

PEi: export price;

$\mathrm{PM}_{\mathrm{i}}$ : import price;

$\mathrm{YF}_{\mathrm{f}}$ : income of primary input $\mathrm{f}$;

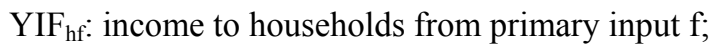

$\mathrm{BI}_{\mathrm{hf}}$ : income to business from primary input $\mathrm{f}$;

$\mathrm{YI}_{\mathrm{h}}$ : income of households $\mathrm{h}$;

$\mathrm{BI}$ : income to business;

GI: government income;

EG: government expenditure;

EXR: exchange rate (local currency unit per foreign currency unit);

$\mathrm{WF}_{\mathrm{f}}$ : average price of primary input;

$\overline{\mathrm{QIN}}$ : initial quantitative of investment demand for commodity i;

$\overline{\mathrm{QG}}$ : initial government consumption demand for commodity i;

pwm $_{\mathrm{i}}$ : import price of commodity i (foreign currency);

pwe $_{\mathrm{i}}$ : export price of commodity i (foreign currency);

$\mathrm{MPS}_{\mathrm{h}}$ : marginal propensity to save for household $\mathrm{h}$;

WFDIST $_{\mathrm{fi}}$ : wage distortion factor for factor $\mathrm{f}$ in commodity $\mathrm{I}$;

CPI: consumer price index;

$\mathrm{T}_{\text {ins }}$ : direct tax of institution ins;

$\mathrm{T}_{\text {ins h }}$ : direct tax of household h;

$\mathrm{T}_{\text {vai }}$ : value-added tax of commodity $\mathrm{i}$;

$\mathrm{T}_{\mathrm{mi}}$ : import tariff of commodity $i$;

$\mathrm{T}_{\mathrm{ei}}$ : export tariff of commodity $\mathrm{i}$;

$\operatorname{Tr}_{\mathrm{Fb}}$ : transfer from foreign to business;

$\mathrm{Tr}_{\mathrm{gh}}$ : transfer from government to households $\mathrm{h}$;

$\mathrm{Tf}_{\mathrm{Fh}}$ : transfer from foreign to households $\mathrm{h}$;

$\mathrm{Ta}_{\mathrm{i}}$ : indirect tax of commodity $\mathrm{i}$.

\section{Parameters}

$\alpha_{\mathrm{fi}}$ : share parameter for CES activity production function of activity $\mathrm{i}$;

$-\rho_{\text {ces i }}$ : CES activity production function exponent;

$\mathrm{A}_{\text {ces } \mathrm{i}}$ : shift parameter for CES activity production function of activity $\mathrm{i}$;

$\beta_{\mathrm{hi}}$ : marginal share of consumption spending on marketed commodity $\mathrm{i}$ for household $\mathrm{h}$;

$\mathrm{A}_{\mathrm{ij}}$ : input output coefficient;

$-\rho_{\text {cet } i}$ : CET function exponent;

$-\rho_{\text {am } \mathrm{i}}$ : armington function exponent;

$\alpha_{\text {cet } i}$ : share parameter for CET function;

$\mathrm{A}_{\text {cet } \mathrm{i}}$ : shift parameter for CET function;

$\alpha_{\mathrm{am} i \mathrm{i}}$ : share parameter for Armington function;

$\mathrm{A}_{\mathrm{am}} \mathrm{i}$ : shift parameter for Armington function;

$\Theta_{h f}$ : proportion of income from primary input $f$ to household $h$; 
$\Theta_{b f}$ : proportion of income from primary input $f$ to business $b$;

INTA $_{\mathrm{i}}$ : quantity of aggregate intermediate input per activity unit;

IVA $_{\mathrm{i}}$ : quantity of value-added per activity unit.

\section{Copyrights}

Copyright for this article is retained by the author(s), with first publication rights granted to the journal.

This is an open-access article distributed under the terms and conditions of the Creative Commons Attribution license (http://creativecommons.org/licenses/by/3.0/). 